\title{
Effects of Band Therapy Using Music on Grasping Power, Depression, and Personal Relationships in Nursing-Home-Dwelling Elderly Individuals
}

\author{
Eun Kyung Chang1, Heeok Park ${ }^{2 *}$, Miran Jung³, Hae Kyeong Lee ${ }^{4}$, Jieun Park , Mijung Park², \\ Minsuk Gang6 \\ ${ }^{1}$ Nursing Department, Daegu Health College, Daegu, South Korea \\ ${ }^{2}$ College of Nursing, Keimyung University, Daegu, South Korea \\ ${ }^{3}$ Nursing Department, Daegu Fatima Hospital, Daegu, South Korea \\ ${ }^{4}$ Nursing Department, Keimyung University Dongsan Medical Center, Daegu, South Korea \\ ${ }^{5}$ Nursing Department, Kyungpook National University Medical Center, Daegu, South Korea \\ ${ }^{6}$ School of Nursing, Youngjin College, Daegu, South Korea \\ Email: mayonaka@naver.com, ‘hopark@kmu.ac.kr, miran880313@naver.com, cocolee1747@hanmail.net, jellie9@naver.com, \\ kms4790@naver.com
}

How to cite this paper: Chang, E.K., Park, H., Jung, M., Lee, H.K., Park, J., Park, M. and Gang, M. (2016) Effects of Band Therapy Using Music on Grasping Power, Depression, and Personal Relationships in Nursing-Home-Dwelling Elderly Individuals. Open Journal of Nursing, 6, 958-968. http://dx.doi.org/10.4236/ojn.2016.611092

Received: September 27, 2016 Accepted: November 25, 2016 Published: November 28, 2016

Copyright $\odot 2016$ by authors and Scientific Research Publishing Inc. This work is licensed under the Creative Commons Attribution International License (CC BY 4.0).

http://creativecommons.org/licenses/by/4.0/ (c) (i) Open Access

\section{Abstract}

The current study examined the effects of band therapy using music on grasping power, depression, and personal relationships among residents of a nursing home. Thirty subjects participated in the study. The band therapy included greetings, warmup exercises with music, singing with dance, playing instruments, closing speech, and stretching with background music. Band therapy was held for 40 minutes once per week, for a total of four sessions, in the activity room of the nursing home. Findings showed that grasping power, depression, and personal relationships were improved at posttest, but the differences were not statistically significant. A better study design to compare the effects of band therapy with the other group, and a more simple and repeated intervention for the elderly to follow without stress might be necessary.

\section{Keywords}

Band Therapy, Music, Grasping Power, Depression, Personal Relationships, Nursing Home

\section{Introduction}

The number of older adults in South Korea has increased to $21 \%$ of the population over 
the past 5 years, and the percentage of older adults staying at long-term care facilities has increased to $57 \%$ over the same period [1]. Older adults staying at nursing homes have diverse health problems, including physical and psychosocial problems. Among them, functional decline, depression, and low levels of social interaction are common, and serious problems must be controlled [2] [3].

Depression is one of the most common psychosocial problems among older adults staying at long-term care facilities [4] [5] and 40 - 48 percent of residents at long-term care facilities show depression, compared to the 33 percent of older adults living in their own home [6]. Depression at long-term care facilities is related to change of living environment, personal interaction and social support system, and isolation from family [7]. Because of depression, residents also show reduced interaction with other residents at the facilities. Although depression is serious and common in long-term care facilities, depression is under-assessed and under-managed by health professionals [8].

Personal relationships are generally defined as relationships among more than two persons and the psychological relationship among members of a group [9]. The lack of personal relationships is related to low self-esteem, depression, loneliness, social/emotional connectedness, isolation, and reduced quality of life, and it is a causal factor in personality disorders and negative social adjustment [10] [11] [12] [13]. Personal relationships are important among elderly individuals, but personal relationships among residents of long-term care facilities have not yet been studied in South Korea.

To improve depression and personal relationships among elderly individuals, diverse interventions such as music intervention, massage therapy, group art therapy, horticultural activities, band therapy, and soon have been implemented [9] [14] [15] [16] [17]. Among them, band therapy is highly recommended to improve depression and personal relationships, as it is inexpensive and easy to provide. Previous studies of band therapy have used elastic bands for physical and psychosocial factors such as pain, fatigue, flexibility, depression, quality of life, and so on [18] [19] [20] [21]. However, the previous studies are limited to healthy or home-dwelling elderly individuals or those using community health centers [18] [20] [22], so there is a need to investigate the effects of elastic bands on grasping power, depression, and personal relationships for residents staying at long-term care facilities. The purpose of the current study was to test the effects of band therapy on grasping power, depression, and personal relationships among residents at long-term care facilities.

\section{Methods}

\subsection{Participants}

The study was a quasi-experimental one-group pretest/posttest design. Participants were 30 elderly individuals staying at a nursing home in D-city, South Korea. Convenience sampling was used. Inclusion criteria were as follows: 65 or older, no physical impairment, ability to communicate, understood the purpose of study, and willing to participate in the study. The minimum size of a group was 27 based on the $G{ }^{*}$ Power 
3.1. Program analysis [23] with moderate effect size of 0.50 , power of 0.80 , and alpha value of 0.50 . Therefore, the number of participants in this study satisfied the minimum samples size.

\subsection{Instruments}

- Grasping power

Grasping power was measured using a dynamometer (Lavisen's KS-301). For the measurement, subjects stand upright, straighten their arms to the side, and drop them until they are $15^{\circ}$ from the body. A subject grasps the dynamometer with one hand while the second finger is at $90^{\circ}$. When the PI says "start," the subject grasps the dynamometer as hard as possible. S/he repeats the process one more time with the other hand and the better record is kept. The dynamometer results are measured in kilograms, recorded to one decimal point.

- Depression

Depression was measured using the Korean version of the Geriatric Depression Scale-Short Form (GDS-SF) [24]. The GDS-SF Korea version includes 15 items, and each item is answered with yes (1) or no (0), for a total possible range of 0 to 15 . Higher scores reflect greater depression, and scores over 5 reflect depression. The reliability of the GDS-SF is 0.88 [24].

- Personal relationships

To measure personal relationships, the modified Relationship Change Scale (RCS) was used [25]. The original RCS consists of 25 items, and it was modified in Park's (1998) study [26]. The modified RCS includes only 7 items, and each item is answered from 1 (never happened) to 4 (always happens). Higher scores reflect better personal relationships, and the reliability of the RCS is 0.77 [26].

\subsection{Band Therapy Using Music}

Band therapy using music was primarily developed by the PI and the authors based on the results of a literature review [27] [28] [29] [30], and the first draft of band therapy was modified by the nursing faculty. The band therapy method is presented in Table 1 , and the contents of band therapy consist of an introduction (5 minutes), development (30 minutes), and closing (5 minutes). The introduction includes introduction greetings and warm-up exercises with background music. The development stage includes singing with dance and playing instruments, and the closing stage includes closing speech and stretching with background music. Band therapy was provided by the PI and four research assistants in the activity room of a long-term care facility for $40 \mathrm{mi}$ nutes at a time, and a total of four sessions (Thursday, once a week).

The music for band therapy changed every week, including "say hi like this," "spring of hometown," "goodbye song," and so on. During the therapy, rhythm instruments, such as a drum, tambourine, triangle, and castanets were used to promote easy use. The PI demonstrated how to use the band and the music instruments. The other authors helped participants with the therapy during each session. 
Table 1. Band therapy using music.

\begin{tabular}{|c|c|c|c|c|c|}
\hline Session & \multicolumn{2}{|c|}{ Composition } & Contents & Preparation & Title of song \\
\hline \multirow{4}{*}{1} & \multicolumn{2}{|c|}{ Introduction (5mins) } & $\begin{array}{l}\text { - Introduction \& greetings ( } 2 \text { mins) } \\
\text { - Warm-up exercise with background music ( } 3 \mathrm{~min})\end{array}$ & $\begin{array}{l}\text { - } \quad \text { Vim project tor \& PC } \\
\text { Background music with } \\
\text { CD player }\end{array}$ & $\begin{array}{c}\text { Say hi like } \\
\text { this }\end{array}$ \\
\hline & \multirow[b]{2}{*}{$\begin{array}{l}\text { Development } \\
\text { (30mins) }\end{array}$} & $\begin{array}{l}\text { Singing with } \\
\text { dance } \\
(15 \text { mins })\end{array}$ & $\begin{array}{l}\text { - Sing a song with clapping alone and together ( } 3 \text { mins) } \\
\text { - Sing a song \& dancing using band (pulling band alone or with } \\
\text { a partner) ( } 15 \text { mins) }\end{array}$ & $\begin{array}{l}\text { - Sera band } \\
\text { Background music with } \\
\text { CD player }\end{array}$ & $\begin{array}{c}\text { Spring of } \\
\text { home-town }\end{array}$ \\
\hline & & \multirow[t]{2}{*}{$\begin{array}{l}\text { Rhythm musical } \\
\text { instrument } \\
\text { (15 mins) }\end{array}$} & $\begin{array}{l}\text { - Introduction how to use rhythm musical } \\
\text { instrument (5 mins) } \\
\text { - Play rhythm musical instrument all together (5 mins) } \\
\text { - Play rhythm musical instrument personally (15 mins) }\end{array}$ & \multirow[t]{2}{*}{$\begin{array}{l}\text { Piano, a base drum, a } \\
\text { small drum, tambourine, } \\
\text { triangle, castanets }\end{array}$} & $\begin{array}{l}\text { My pleasant } \\
\text { home }\end{array}$ \\
\hline & $\begin{array}{l}\text { Closing } \\
(5 \mathrm{mins})\end{array}$ & & $\begin{array}{l}\text { - } \quad \text { Closing speech ( } 2 \text { mins) } \\
\text { - } \quad \text { Stretching with background music (good bye song) (3 mins) }\end{array}$ & & $\begin{array}{l}\text { Good bye } \\
\text { song }\end{array}$ \\
\hline \multirow{4}{*}{2} & \multicolumn{2}{|c|}{ Introduction (5mins) } & $\begin{array}{l}\text { - } \quad \text { Introduction ( } 2 \text { mins) } \\
\text { - Warm-up exercise with background music ( } 3 \text { mins) }\end{array}$ & $\begin{array}{l}\text { - } \quad \text { Vim projector \&PC } \\
\text { Background music with } \\
\text { CD player }\end{array}$ & $\begin{array}{l}\text { Say hi } \\
\text { like this }\end{array}$ \\
\hline & \multirow[b]{2}{*}{$\begin{array}{l}\text { Development } \\
\text { (30mins) }\end{array}$} & $\begin{array}{c}\text { Singing with } \\
\text { dance (20 mins) }\end{array}$ & $\begin{array}{l}\text { - Sing a song with clapping alone and together ( } 3 \text { mins) } \\
\text { - Sing a song } \& \text { dancing using band (pulling band alone or with } \\
\text { a partner) ( } 17 \text { mins) }\end{array}$ & $\begin{array}{l}\text { - } \\
\text { Bera band } \\
\text { CD player }\end{array}$ & $\begin{array}{l}\text { Gunbam } \\
\text { taryeong }\end{array}$ \\
\hline & & \multirow[t]{2}{*}{$\begin{array}{l}\text { Rhythm musical } \\
\text { instrument } \\
\text { (10 mins) }\end{array}$} & $\begin{array}{l}\text { - Introduction how to use rhythm musical instrument (2 mins) } \\
\text { - Play rhythm musical instrument personally ( } 3 \text { mins }) \\
\text { - } \quad \text { Play rhythm musical instrument all together (5 mins) }\end{array}$ & \multirow[t]{2}{*}{$\begin{array}{l}\text { - Piano, a base drum, a } \\
\text { small drum, tambourine, } \\
\text { triangle, castanets }\end{array}$} & $\begin{array}{l}\text { My pleasant } \\
\text { home }\end{array}$ \\
\hline & $\begin{array}{l}\text { Closing } \\
(5 \text { mins })\end{array}$ & & $\begin{array}{l}\text { - } \quad \text { Closing speech ( } 2 \text { mins) } \\
\text { - } \quad \text { Stretching with background music (good bye song) (3 mins) }\end{array}$ & & $\begin{array}{l}\text { Good bye } \\
\text { song }\end{array}$ \\
\hline \multirow{4}{*}{3} & \multirow{3}{*}{$\begin{array}{l}\text { Development } \\
\text { (30 mins) }\end{array}$} & ion (5 mins) & $\begin{array}{l}\text { - Introduction \& greetings ( } 2 \text { mins) } \\
\text { - Warm-up exercise with background music ( } 3 \text { mins) }\end{array}$ & $\begin{array}{l}\text { - } \quad \text { Vim projector \& PC } \\
\text { Background music with } \\
\text { CD player }\end{array}$ & $\begin{array}{l}\text { Say hi } \\
\text { like this }\end{array}$ \\
\hline & & $\begin{array}{l}\text { Singing with } \\
\text { dance } \\
(20 \text { mins })\end{array}$ & $\begin{array}{l}\text { - Sing a song with clapping alone and together ( } 3 \text { mins) } \\
\text { - Sing a song \& dancing using band(pulling band alone or with } \\
\text { a partner) (17 mins) }\end{array}$ & $\begin{array}{l}\text { - } \\
\text { - Background music with } \\
\text { CD player }\end{array}$ & $\begin{array}{c}\text { Blossom \& } \\
\text { blossom }\end{array}$ \\
\hline & & $\begin{array}{l}\text { Rhythm musical } \\
\text { instrument } \\
\text { (10 mins) }\end{array}$ & $\begin{array}{l}\text { - Introduction how to use rhythm musical instrument(2 mins) } \\
\text { - } \quad \text { Play rhythm musical instrument all together (8 mins) }\end{array}$ & $\begin{array}{l}\text { Piano, a base drum, a } \\
\text { small drum, tambourine, } \\
\text { triangle, castanets }\end{array}$ & $\begin{array}{c}\text { My pleasant } \\
\text { home }\end{array}$ \\
\hline & $\begin{array}{l}\text { Closing } \\
(5 \text { mins })\end{array}$ & & $\begin{array}{l}\text { - } \quad \text { Closing speech ( } 2 \text { mins) } \\
\text { - } \quad \text { Stretching with background music (good bye song) (3 mins) }\end{array}$ & & $\begin{array}{l}\text { Good bye } \\
\text { song }\end{array}$ \\
\hline \multirow{4}{*}{4} & \multirow{3}{*}{$\begin{array}{l}\text { Development } \\
(30 \text { mins })\end{array}$} & $\operatorname{tion}(5 \operatorname{mins})$ & $\begin{array}{l}\text { - Introduction \& greetings ( } 2 \text { mins) } \\
\text { - Warm-up exercise with background music ( } 3 \text { mins })\end{array}$ & $\begin{array}{l}\text { - } \quad \text { Vim projector \& PC } \\
\text { Background music with } \\
\text { CD player }\end{array}$ & $\begin{array}{c}\text { Say hi like } \\
\text { this }\end{array}$ \\
\hline & & $\begin{array}{l}\text { Singing with } \\
\text { dance } \\
(20 \text { mins })\end{array}$ & $\begin{array}{l}\text { - Sing a song with clapping alone and together( } 3 \text { mins) } \\
\text { - Sing a song \& dancing using band (pulling band alone or with } \\
\text { a partner) (12 mins) }\end{array}$ & $\begin{array}{l}\text { - Sera band } \\
\text { Background music with } \\
\text { CD player }\end{array}$ & Arirang \\
\hline & & $\begin{array}{l}\text { Rhythm musical } \\
\text { instrument } \\
\text { (10 mins })\end{array}$ & $\begin{array}{l}\text { - Introduction how to use rhythm musical instrument (3 mins) } \\
\text { - } \quad \text { Play rhythm musical instrument personally (3 mins) } \\
\text { - } \quad \text { Play rhythm musical instrument all together (12 mins) }\end{array}$ & $\begin{array}{l}\text { - Piano, a base drum, a } \\
\text { small drum, tambourine, } \\
\text { triangle, castanets }\end{array}$ & $\begin{array}{c}\text { My pleasant } \\
\text { home }\end{array}$ \\
\hline & $\begin{array}{l}\text { Closing } \\
(5 \mathrm{mins})\end{array}$ & & $\begin{array}{l}\text { - } \quad \text { Closing speech ( } 2 \text { mins) } \\
\text { - } \quad \text { Stretching with background music (good bye song) ( } 3 \text { mins) }\end{array}$ & & $\begin{array}{l}\text { Good bye } \\
\text { song }\end{array}$ \\
\hline
\end{tabular}




\subsection{Data Collection}

This study was approved by the Institutional Review Board at K University and the data collection was performed from November to December 2015 after receiving IRB approval. The PI and co-authors visited S-nursing home and first presented the purpose of the study to the director. After the presentation, the director allowed the authors to present the contents of the study to residents of the nursing home. When the presentation was completed and subjects expressed desire to participate, formal written consent was obtained from the subject or his/her legal representatives. After formal consent was obtained, data collection began. The PI explained that the subjects could withdraw from the study at any time. The PI emphasized that the data would be kept in a locked cabinet.

A pretest was conducted right before the first session of the exercise program. The pretest included subject characteristics, grasping power, depression, and personal relationships. After the final session of the program, the posttest, including grasping power, depression, and personal relationships, was conducted. When it was hard for participants to answer the questionnaires, their medical records were used.

\subsection{Data Analysis}

Data analysis was performed using SPSS version 18.0. Descriptive statistics were used to describe participant characteristics, and paired t-tests were used to compare differences in grasping power, depression, and personal relationships between the pretest and posttest.

\section{Results}

\subsection{Subject Characteristics}

General characteristics of participants are presented in Table 2. The majority of participants were older than 80 (69.0\%), female (90.0\%), Christian (60.0\%), widowed (76.7\%), and had no education (60.0\%). Most participants had no family visits $(60.0 \%)$, low economic status $(93.3 \%)$, poor health status $(70.0 \%)$, and engaged in outdoor activity more than 1 hour per day (66.7\%). Disease-related characteristics of participants are presented in Table 3. The majority of participants had hypertension $(63.3 \%)$, disease above 5 years $(70.0 \%)$, and took medications related to hypertension (93.3\%). Most participants had poor cognitive status (60.0\%) and lived at this nursing home for more than 6 years (56.7\%).

\subsection{Differences in Grasping Power, Depression, and Personal Relationships}

Differences in grasping power, depression, and personal relationships are presented in Table 4. The mean level of grasping power in the pretest was $18.13 \pm 9.91 \mathrm{~kg}$ and decreased to $15.40 \pm 6.45 \mathrm{~kg}$ in the posttest. The difference in grasping power level between pretest and posttest was not significant $(t=1.50, p=0.144)$. The mean level of 
depression in the pretest was $7.45 \pm 3.46$ and decreased to $6.27 \pm 3.42$ in the posttest. This difference was not significant $(t=1.70, \mathrm{p}=0.099)$. The mean personal relationships score in the pre-test was $19.97 \pm 3.27$, and this increased to $20.79 \pm 3.98$ in the posttest. This difference was also not significant $(t=-0.95, \mathrm{p}=0.348)$.

\section{Discussion}

The current study investigated the use of band therapy for residents at a long-term care facility and measured its effect on grasping power, depression, and personal relationships. Results showed that grasping power, depression, and personal relationships improved at posttest compared to pretest, but the differences were not statistically significant. Even though the differences were not significant, the current study is meaningful because nursing-home-dwelling elderly have not been studied enough in Korea.

Table 2. General characteristics of participants $(\mathrm{N}=30)$.

\begin{tabular}{|c|c|c|c|}
\hline Characteristics & Categories & $\mathrm{n}$ & $\%$ \\
\hline \multirow[t]{5}{*}{ Age $(N=29)$} & $\mathrm{M} \pm \mathrm{SD}$ & 82.90 & 5.67 \\
\hline & $68 \sim 80$ & 10 & 33.3 \\
\hline & $81 \sim 85$ & 7 & 24.1 \\
\hline & $86 \sim 90$ & 11 & 37.9 \\
\hline & $>90$ & 2 & 7.0 \\
\hline \multirow[t]{2}{*}{ Gender } & Male & 3 & 10.0 \\
\hline & Female & 27 & 90.0 \\
\hline \multirow[t]{4}{*}{ Religion } & Christianity & 18 & 60.0 \\
\hline & Buddhism & 4 & 13.3 \\
\hline & None & 5 & 16.7 \\
\hline & Other & 3 & 10.0 \\
\hline \multirow[t]{4}{*}{ Marital status } & Widowed & 23 & 76.7 \\
\hline & Not-married & 4 & 13.3 \\
\hline & other & 3 & 10.0 \\
\hline & None & 18 & 60.0 \\
\hline \multirow[t]{2}{*}{ Educationlevel } & Elementary & 11 & 36.7 \\
\hline & Middle & 1 & 3.3 \\
\hline \multirow{2}{*}{$\begin{array}{l}\text { Family visiting } \\
\text { (a month) }\end{array}$} & Yes & 12 & 40.0 \\
\hline & No & 18 & 60.0 \\
\hline \multirow[t]{2}{*}{ Economical status } & Middle & 2 & 6.7 \\
\hline & Low & 28 & 93.3 \\
\hline \multirow[t]{4}{*}{ Health status } & Good & 2 & 6.7 \\
\hline & Fair & 7 & 23.3 \\
\hline & Bad & 21 & 70.0 \\
\hline & $\mathrm{M} \pm \mathrm{SD}$ & 42.0 & 42.86 \\
\hline \multirow{3}{*}{$\begin{array}{l}\text { Total time of a day } \\
\text { outdoor activities in } \\
\text { (min) }\end{array}$} & None & 10 & 33.3 \\
\hline & $<1 \mathrm{hr}$ & 6 & 20.0 \\
\hline & $1 \mathrm{hr} \sim 3 \mathrm{hr}$ & 14 & 46.7 \\
\hline
\end{tabular}


Table 3. Disease-related characteristics of participants $(N=30)$.

\begin{tabular}{|c|c|c|c|}
\hline Characteristics & Categories & nor Mean & $\%$ or SD \\
\hline \multirow[t]{6}{*}{ Diagnosed disease $^{\mathrm{a}}$} & Hypertension & 19 & 63.3 \\
\hline & Diabetes & 8 & 26.7 \\
\hline & Arthritis & 14 & 46.7 \\
\hline & Dementia & 5 & 16.7 \\
\hline & $\mathrm{M} \pm \mathrm{SD}$ (month) & 137.25 & 110.38 \\
\hline & $\leq 5$ years & 9 & 30.0 \\
\hline \multirow{3}{*}{$\begin{array}{l}\text { Total period of illness } \\
\qquad(\mathrm{n}=26)\end{array}$} & $6-10$ years & 10 & 33.3 \\
\hline & 11 - 20 years & 8 & 26.7 \\
\hline & $>20$ years & 3 & 10.0 \\
\hline \multirow[t]{6}{*}{ Medication $^{\mathrm{a}}$} & Hypertension & 28 & 93.3 \\
\hline & Diabetes & 5 & 16.7 \\
\hline & Dementia & 15 & 50.0 \\
\hline & Antipsychotic & 9 & 30.0 \\
\hline & $\mathrm{M} \pm \mathrm{SD}$ & 20.23 & 7.72 \\
\hline & $\geq 24$ & 12 & 40.0 \\
\hline \multirow{4}{*}{ Cognitive status (MMSE) } & $20-23$ & 4 & 13.3 \\
\hline & $0-19$ & 14 & 46.7 \\
\hline & Diarrhea & 2 & 6.7 \\
\hline & Constipation & 15 & 50.0 \\
\hline \multirow[t]{3}{*}{ Discomfort symptom ${ }^{\mathrm{a}}$} & Thirsty & 12 & 40.0 \\
\hline & Dysuria & 9 & 30.0 \\
\hline & Pain & 22 & 73.3 \\
\hline \multirow[t]{4}{*}{ Marital status } & Widowed & 23 & 76.7 \\
\hline & Not-married & 4 & 13.3 \\
\hline & other & 3 & 10.0 \\
\hline & $\mathrm{M} \pm \mathrm{SD}$ (month) & 88.04 & 69.02 \\
\hline \multirow{3}{*}{$\begin{array}{l}\text { Total period of living facility } \\
\qquad(N=29)\end{array}$} & $\leq 5$ years & 13 & 44.8 \\
\hline & $6 \sim 10$ years & 11 & 36.7 \\
\hline & $11 \sim 20$ years & 6 & 20.7 \\
\hline
\end{tabular}

${ }^{\mathrm{a}}$ Duplicated response.

Table 4. Differences in grasping power, depression and personal relationship $(\mathrm{N}=30)$.

\begin{tabular}{ccccc}
\hline Variable & Pretest $(\mathrm{M} \pm \mathrm{SD})$ & Posttest $(\mathrm{M} \pm \mathrm{SD})$ & $\mathrm{t}$ & $\mathrm{p}$ \\
\hline Grasping power & $18.13 \pm 9.91$ & $15.40 \pm 6.45$ & 1.50 & 0.144 \\
Depression & $7.4 \pm 3.46$ & $6.27 \pm 3.42$ & 1.70 & 0.099 \\
Personal relationship & $19.97 \pm 3.27$ & $20.79 \pm 3.98$ & -0.95 & 0.348 \\
\hline
\end{tabular}

In the current study, grasp power improved, but the improvement was not significant. In Ponce-Bravo and colleagues' study, grip strength improved in the functional resistance-band exercises group compared to the recreation-oriented exercise group [31]. The band exercise group, comprised of active older adults, completed functional 
exercises with elastic bands, aerobics, gross motor activity, action/reaction speed, and floor exercises. In addition, band exercise was provided in 20 sessions over 4 weeks for active older adults in the community, and the intensity of the exercise was modulated according to the expert's perception of each training session. Based on the comparisons, band therapy to improve grasping power needs to include gross motor exercises focused on functional exercises, as well as more planned exercise programs for nursing home elderly. In Kim et al.'s (2013) study [32], the Qi-gong exercise and elastic band exercise group improved grip strength in healthy elderly women in the community compared to the no exercise group. Band exercise was provided 3 times/week and included 10 sessions. However, it is difficult for health professionals to provide interventions such as band exercise more than once a week in nursing homes. Thus, band exercise needs to be more intense to improve grip strength among nursing-home-dwelling elderly.

In the current study, depression (7.44) at pre-intervention improved to 6.48 at postintervention, but it was not statistically significant. In Kim et al.'s (2013) study [32], depression at pre-intervention (8.06) improved to 4.93 at post-intervention in the band exercise group, and the difference between the two groups was significant. The lack of a significant difference in depression level in the present study might have resulted from insufficient program duration. Further, nursing home elderly may be at greater risk of depression because of factors such as pain, lack of social contact, and length of stay [33]. Further studies of band therapy should include exercises to improve social contact among nursing-home-dwelling elderly.

During the intervention period, band therapy was provided with music. For the first time, the same music was provided four times in a row, and this may have bored the participants. For future studies, depending on participants' music preferences, a diverse variety of music needs to be provided with the band therapy from the outset. In addition, even participants with poor cognitive function can follow the beat of percussion instruments for the exercise, and so future studies are highly encouraged to use percussion instruments, and it is further encouraged for band therapy to indicate the start and direction of each motion in the exercise.

During the intervention, some participants were very excited to perform the band therapy with music, and they exercised with the band in their own way. On the other hand, other participants sometimes complained that it was difficult to follow the entire process of band therapy. Accordingly, further studies should implement individualized band therapy to meet the cognitive and functional levels of individual participants. Participants also did not prefer fast-paced music for band therapy, instead preferring music with a tolerable speed and familiar lyrics for them to sing and follow along easily. Thus, the contents of band therapy need to be simple and repeated for participants to follow the instructor's demonstration. Also, the current study was performed with only one group so the study needs to be provided with a control group for the further studies.

The current study was performed at one nursing home, and so generalizability is li- 
mited. In this study, band therapy was provided in an experimental group without a control group. For future studies, a control group needs to be provided for the comparison of outcomes between the two groups. In terms of nursing home conditions, band therapy was performed only once a week for a total of four sessions. For effective results, it should be provided more than four times to investigate longer-term effects of the intervention.

\section{Conclusion}

Band therapy improved grip power, depression, and personal relationships, but the effects were not statistically significant. For nursing-home-dwelling elderly individuals, it is possible that band therapy needs to be intense with exercises to improve cognitive and functional status over long periods.

\section{Acknowledgements}

The authors thank all participants and nurses in the nursing-home to help the study completed. This research was supported by Basic Science Research Program through the National Research Foundation of Korea (NRF) funded by the Ministry of Education (No. 2015R1D1A3A01017843).

\section{References}

[1] National Health Insurance Corporation (2015) 2014 Health Insurance Statistics, Korea.

[2] Kim, S.M., Lee, H.K. and Sok, S.H. (2009) Activities of Daily Living and Nursing Needs of the Elderly in Nursing Home. Journal of Korean Academy of Community Health Nursing, 20, 1-11. http://dx.doi.org/10.4040/jkan.2009.39.1.1

[3] Jongenelis, K., Pot, A.M., Eisses, A.M.H., Beekman, A.T.F., Kluiter, H. and Ribbe, M.W. (2004) Prevalence and Risk Indicators of Depression in Elderly Nursing Home Patients: The AGED Study. Journal of Affective Disorders, 83, 135-142. http://dx.doi.org/10.1016/j.jad.2004.06.001

[4] Barca, M.L., Engedal, K., Laks, J. and Selbaek, G. (2010) A 12 Months Follow-Up Study of Depression among Nursing-Home Patients in Norway. Journal of Affective Disorders, 120, 141-148. http://dx.doi.org/10.1016/j.jad.2009.04.028

[5] Ha, M.S. and Park, R.J. (2008) A Study of Cognitive Function and Depression of the Elderly in an Institution. Journal of the Korean Society of Physical Medicine, 3, 285-292.

[6] Ministry and Health Welfare (2014) 2014 Aged Statistics, Korea.

[7] Park, G.J., Lee, J.H., Bae, K.E., Kang, Y.H. and Song, H.S. (2007) Self-Esteem and Depression of Elders in Welfare Facilities. Journal of Korean Gerontological Nursing, 9, 51-59.

[8] Levin, C.A., Wei, W., Akincigil, A., Lucas, J.A., Bilder, S. and Crystal, S. (2007) Prevalence and Treatment of Diagnosed Depression among Elderly Nursing Home Residents in Ohio. Journal of the American Medical Directors Association, 8, 585-594. http://dx.doi.org/10.1016/j.jamda.2007.07.010

[9] Yoon, H.J. and Shim, U.B. (2013) The Effects of Grouping Musical Therapy on Old Solitary Women's Depression, Personal Relationship, Satisfactions of Living. Korean Journal of Welfare Counseling, 7, 1-18.

[10] Ra, H.S. (2006) The Effect of Gestalt Group Arts Therapy on Interpersonal Relationships of 
Client. Korean Journal of Art Therapy, 13, 361-385.

[11] Park, Y.B. (2002) A Study on the Influential Factors on the Old's Loneliness in Welfare Centers. Unpublished Master's Thesis, Mokwon University, Daejeon.

[12] Hatfield, J.P., Hirsch, J.K. and Lyness, J.M. (2013) Functional Impairment, Illness Burden, and Depressive Symptoms in Older Adults: Does Type of Social Relationship Matter? International Journal of Geriatric Psychiatry, 28, 190-198. http://dx.doi.org/10.1002/gps.3808

[13] Powers, A.D., Gleason, M.E. and Oltmanns, T.F. (2013) Symptoms of Borderline Personality Disorder Predict Interpersonal (But Not Independent) Stressful Life Events in a Community Sample of Older Adults. Journal of Abnormal Psychology, 122, 469-474. http://dx.doi.org/10.1037/a0032363

[14] Park, E.M. and Lee, M.A. (2006) A Study in the Effects of Group Art Therapy on the Elderly's Human Relationship in the Aged Day Care Center. Korean Journal of Art Therapy, 13, 915-936.

[15] Chan, M.F., Wong, Z.Y., Onishi, H. and Thayala, N.V. (2012) Effects of Music on Depression in Older People: A Randomized Controlled Trial. Journal of Clinical Nursing, 21, 776-783. http://dx.doi.org/10.1111/j.1365-2702.2011.03954.x

[16] Seo, S.Y. and Chang, S.Y. (2009) Effects of Aroma Hand Massage On Sleep, Depression and Quality of Life in the Institutionalized Elderly Women. Korean Journal of Women Health Nursing, 15, 372-380. http://dx.doi.org/10.4069/kjwhn.2009.15.4.372

[17] Rappe, E. and Kivelä, S.L. (2005) Effects of Garden Visits on Long-Term Care Residents as Related to Depression. HortTechnology, 15, 298-303.

[18] Park, S.Y., Kim, J.K. and Lee, S.A. (2015) The Effects of a Community-Centered Muscle Strengthening Exercise Program Using an Elastic Band on the Physical Abilities and Quality of Life of the Rural Elderly. Journal of Physical Therapy Science, 27, 2061-2063. http://dx.doi.org/10.1589/jpts.27.2061

[19] Lee, H.C., Lee, M.L. and Kim, S.R. (2015) Effect of Exercise Performance by Elderly Women on Balance Ability and Muscle Function. Journal of Physical Therapy Science, 27, 989992. http://dx.doi.org/10.1589/jpts.27.989

[20] Chan, S.Y., Kuo, C.C., Chen, K.M., Tseng, W.S., Huang, H.T. and Li, C.H. (2016) Health Promotion Outcomes of a Newly Developed Elastic Band Exercise Program for Older Adults in the Community. The Journal of Nursing Research, 24, 137-144. http://dx.doi.org/10.1097/jnr.0000000000000099

[21] Nitsure, P.V., Pathania, T.S. and Bilgi, T.A. (2015) Comparison of Elastic Resistance Band Exercises and Yoga in Physiotherapy Students with Chronic Non-Specific Low Back Pain: A Randomized Clinical Trial. Journal of Yoga \& Physical Therapy, 5, 180.

[22] Yu, W.J., An, C.S. and Kang, H.K. (2013) Effects of Resistance Exercise Using Thera-Band on Balance of Elderly Adults: A Randomized Controlled Trial. Journal of Physical Therapy Science, 25, 1471-1473. http://dx.doi.org/10.1589/jpts.25.1471

[23] Cohen J. (1998) Statistical Power Analysis for the Behavioral Sciences. 2nd Edition, Lawrence Erlbaum Associates, Mahwah.

[24] Kee, B.S. (1996) A Preliminary Study for the Standardization of Geriatric Depression Scale Short Form-Korea Version. Journal of Korean Neuropsychiatric Association, 35, 298-307.

[25] Schlein, A. and Guerney, B.G. (1971) Relationship Enhancement. Josey-Bass, San Francisco.

[26] Park, H.S. (1998) The Development Mechanism of School Resilience of Korean Adolescents in Poverty. Korean Journal of Youth Studies, 5, 147-165.

[27] Kim, S.M., Lee, Y.J. and Kim, H.J. (2009) Effect of Resistance Training on Joint Flexibility 
and Muscle Strength of Upper Extremities of Elderly with Impaired Cognition. Journal of the Korean Gerontological Society, 29, 987-1000.

[28] Jeon, E.Y., Kim, S.Y. and Yoo, H.S. (2009) Effects of Music Therapy and Rhythmic Exercise on Quality of Life, Blood Pressure and Upper Extremity Muscle Strength in InstitutionDwelling Elderly Women. Journal of Korean Academy of Nursing, 39, 829-839. http://dx.doi.org/10.4040/jkan.2009.39.6.829

[29] Seo, K.H. (2010) The Effect of Therapeutic Music Activities Using the Call \& Response Singing Form on the Reduction of Loneliness and the Improvement of Interpersonal Relations of the Senior Citizen Living at a Nursing Home. Korean Journal of Music Therapy, 12, 19-38.

[30] Choi, A.N., Kim, Y.H. and Cheung, K.J. (2010) A Study on the Effects of Music Therapy Activity on Day-Care Elders Cognitive Function and Depression. Journal of Arts Psychotherapy, 6, 103-121.

[31] Ponce-Bravo, H., Ponce, C., Feriche, B. and Padial, P. (2015) Influence of Two Different Exercise Programs on Physical Fitness and Cognitive Performance in Active Older Adults: Functional Resistance-Band Exercises vs. Recreational Oriented Exercises. Journal of Sports Science \&Medicine, 14, 716-722.

[32] Kim, Y.S., Kim G.C., Lee J.W., Kim C.T., Oh, M.J. and Kwak Y.S. (2013) The Effects of QiGong Exercise and Elastic Band Exercise on Fitness, ADL and Depression in Elderly Women. Journal of Wellness, 8, 293-302.

[33] Tiong, W.W., Yap, P., Huat Koh, G.C., Phoon Fong, N. and Luo, N. (2013) Prevalence and Risk Factors of Depression in the Elderly Nursing Home Residents in Singapore. Aging \& Mental Health, 17, 724-731. http://dx.doi.org/10.1080/13607863.2013.775638

\section{Submit or recommend next manuscript to SCIRP and we will provide best service for you:}

Accepting pre-submission inquiries through Email, Facebook, LinkedIn, Twitter, etc. A wide selection of journals (inclusive of 9 subjects, more than 200 journals)

Providing 24-hour high-quality service

User-friendly online submission system

Fair and swift peer-review system

Efficient typesetting and proofreading procedure

Display of the result of downloads and visits, as well as the number of cited articles

Maximum dissemination of your research work

Submit your manuscript at: http://papersubmission.scirp.org/

Or contact ojn@scirp.org 